\title{
Delayed presentation of a thorn prick as an intramedullary abscess
}

Radhey Shyam Mittal, Ashok Gandhi, Achal Sharma, Jitender Shekawath, Ronyl Kaushal

Department of Neurosurgery, Sawai Man Singh Hospital, Jaipur, Rajasthan, India

\section{A B S T R A C T}

Penetrating injury to the spine is the third most common cause of spinal injury. Injuries due to bullet, glass, nails and pencil injuries are well documented in literature. We report a rare case of delayed onset intramedullary abscess following thorn prick and have reviewed the literature for similar forms of injuries.

Key words: Acacia thorn injury of spine, intramedullary abscess, penetrating spinal injury

\section{INTRODUCTION}

Penetrating injury is the third most common cause of spinal injury in America. ${ }^{[1]}$ Bullet injuries to the spine and spinal cord have been adequately covered in literature. However, other types of foreign bodies are also responsible for the penetrating injuries to the spine, for example knife, ${ }^{[2]}$ fragment of glass, ${ }^{[2]}$ nail, ${ }^{[3]}$ pencil lead, ${ }^{[4]}$ and sugar cane ${ }^{[5]}$ which may present months to years after the injury due to reactive tissue formation. We herein present a case of intramedullary abscess formation due to a retained thorn of Acacia.

\section{CASE REPORT}

An eight-year-old male child presented with progressive spastic paraparesis and sensory loss numbness below the umbilicus with bladder and bowel involvement for the past three months. MRI of the thoracolumbar spine showed an intramedullary lesion at D11. D12level [Figures 1a-c], which was presumed to be an intramedullary tumor, most likely an ependymoma. During surgery, we found a fibrous firm tract in the subcutaneous tissue which was going in between the spinus process of D11-D12. Laminectomy was done following which red granulation tissue was seen covering

\begin{tabular}{|l|l|}
\hline \multicolumn{2}{|c|}{ Access this article online } \\
\hline Quick Response Code: & Website: \\
\hline & www.ijns.in \\
\cline { 2 - 2 } & \\
\hline
\end{tabular}

the dura [Figure 1d]. The dura was incised and opened exposing the cord which showed granulation tissue coming out through it. A myelotomy was done, the lesion turned out to be an intramedullary abscess with granulation tissue. The subcutaneous tract was excised along with the abscess. The tract was then opened, and inside which we found a thorn of Acacia surrounded by fibrous tissue [Figure 1e].

After the surgery, on further enquiry, the patient's mother told that he fell down from a tree onto a bunch of wood from the bush of Acacia, six months back. Immediately following the fall, the patient had pain in the back with a very small wound, which healed with local treatment.

On reviewing MRI, we found a linear hypointense shadow from the subcutaneous plane to dura at the level of D11-D12 [Figure 1b].

Post operatively, muscle power improved to grade 4/5 while $80 \%$ improvement in sensation was reported at eight month of follow up. However, he was subsequently lost to follow up and then presented seven years later with trophic where of right foot with decreased sensation in L5-S1 dermatome. His muscle power was grade $5 / 5$. His repeat MRI showed bulky cord at D11-D12 level with arachanoiditis [Figure 1f]. He required below knee amputation for his trophic ulcer.

\section{DISCUSSION}

Thorn injuries are common in children and adults, most often presenting as a foreign body embedded in the superficial or subcutaneous tissue, but there are

Address for correspondence: Dr. Radhey Shyam Mittal,

Department of Neurosurgery, Sawai Man Singh Hospital, Jaipur, Rajasthan, India. E-mail: dr_mittal@hotmail.com 

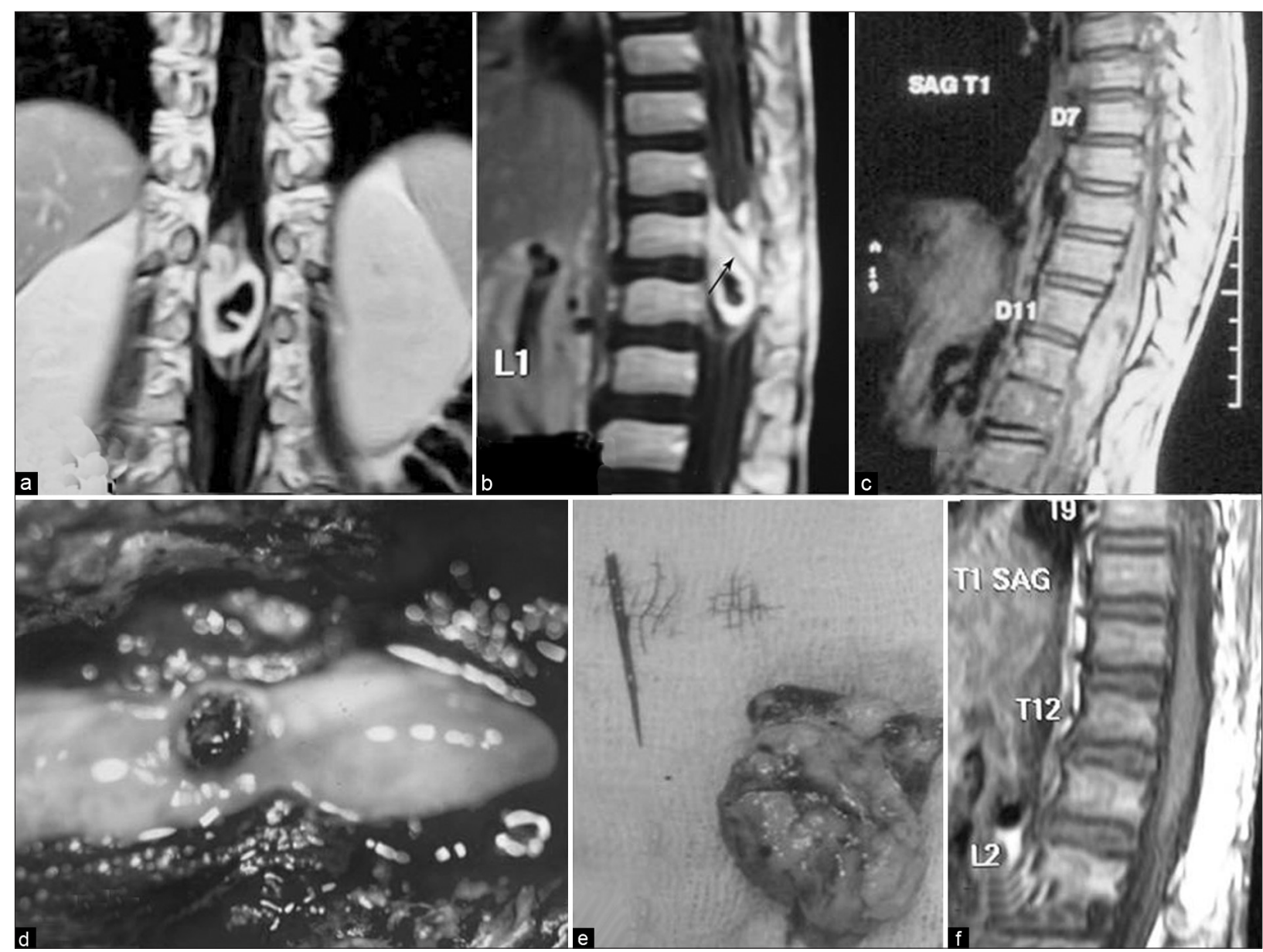

Figure 1: (a-c) MRI images showing an intramedullary lesion; (d) Intra operative photograph showing granulation over the cord; (e) Excised abscess and the thorn which was inside it; (f) Postoperative MRI seven years after surgery

reports of retained thorn causing septic or aseptic arthritis of various joints, osteomyelitis of the foot ${ }^{[6]}$ and tenosynovitis. ${ }^{[7]}$ The most common error in the management of foreign body is the failure to detect it, particularly in children where the unusual nature of the injuries complicates a limited or nonexistent history. In suspected cases, it is important to obtain a careful history, inquiring about the nature and composition of the material involved. Wood, thorn, and other vegetative foreign bodies are considered as more toxic, allergenic and septic ${ }^{[8]}$ than glass, metal or plastic which are relatively inert materials. That is why penetrating organic foreign bodies should be removed as soon as possible before inflammation or infection sets in. ${ }^{[9]}$

Wooden pieces are usually not seen in plain X-ray, but can be detected in CT and MRI. Piece is visible in early stage, but becomes isodense as it can absorb water. ${ }^{[10]}$

We couldn't find any case report where a thorn of Acacia was implanted in the cord, but there has been a case report of a sharp sugar cane piece causing cord compression six years following trauma. ${ }^{[5]}$

\section{CONCLUSION}

Retained thorn in the spinal cord with the formation of an intramedullary abscess is being reported for the first time. A retained vegetative foreign body is known to cause toxic reaction or infection, making it imperative that they are diagnosed early and removed as soon as possible.

In patients presenting with unusual finding on imaging, presenting long after trauma, the possibility of a penetrating injury must be kept in mind. Proper clinical history and clinical examination is of utmost importance in reaching a correct clinical diagnosis.

\section{REFERENCES}

1. David CA, Landy HJ, Green BA. Penetrating wounds of the spine. In: Wilkins RH, Rengachary SS, editors. Neurosurgery. Vol. 2. San Francisco: McGraw-Hill Book Co; 1996. p. 3055-61.

2. William $\mathrm{Q}, \mathrm{Wu} \mathrm{MD}$. Delayed effects from retained foreign bodies in the spine and spinal cord. Surg Neurol 1986;25:214-8.

3. Kryl J, Stulík J, Vyskocil T, Sebesta P. Spinal injury caused by a nail fired from a stud gun. Acta Chir Orthop Tramatol Cech 2006;73:353-5.

4. Meltzer HS, Kim PJ, Ozgur BM, Levy ML. Vertebral body granuloma of the cervical region after pencil injury. Neurosurgery 2004;54:1527-30. 
5. Lunawat SK, Taneja DK. A foreign body in spinal canal: A Case report. J Bone Joint Surg (Br) 2000;82-B:267-8.

6. Vidyadhara S, Rao SK. Thorn prick osteomyelitis of the foot in barefoot walker: A report of four cases. J Orthop Surg 2006;14:222-4.

7. Cahil N, King J. Palm thorn synovitis. J Pediatr Orthop 1984;4:175-9.

8. Sauvezie B, Sirot J. Isolation of Patoea agglomerans in two cases of septic monoarthritis after plant thorn and wood sliver injuries. J Clin Microbiol 2000;38:460-1.

9. Chan C, Salam GA. Splinter removal. Am Fam Physician 2003;67:2557-62.
10. Millar CF, Brodkey JS, Colombi BJ. The danger of intracranial wood. Surg Neurol 1977;7:95-103.

How to cite this article: Mittal RS, Gandhi A, Sharma A, Shekawath J, Kaushal R. Delayed presentation of a thorn prick as an intramedullary abscess. Indian J Neurosurg 2012;1:75-7. Source of Support: Nil, Conflict of Interest: None declared.

\section{New features on the journal's website}

\section{Optimized content for mobile and hand-held devices}

HTML pages have been optimized of mobile and other hand-held devices (such as iPad, Kindle, iPod) for faster browsing speed.

Click on [Mobile Full text] from Table of Contents page.

This is simple HTML version for faster download on mobiles (if viewed on desktop, it will be automatically redirected to full HTML version)

\section{E-Pub for hand-held devices}

EPUB is an open e-book standard recommended by The International Digital Publishing Forum which is designed for reflowable content i.e. the text display can be optimized for a particular display device.

Click on [EPub] from Table of Contents page.

There are various e-Pub readers such as for Windows: Digital Editions, OS X: Calibre/Bookworm, iPhone/iPod Touch/iPad: Stanza, and Linux: Calibre/Bookworm.

\section{E-Book for desktop}

One can also see the entire issue as printed here in a 'flip book' version on desktops. Links are available from Current Issue as well as Archives pages.

Click on View as eBook 